\title{
Extending the Privilege against Self-Incrimination to the Juvenile Waiver Hearing
}

\author{
Sarah Freitasं
}

Minors who commit crimes are commonly placed under the jurisdiction of the state or federal juvenile justice system. Because juvenile status is statutorily rather than constitutionally mandated, juvenile courts may waive jurisdiction over young offenders, sending them to the adult criminal courts for trial. ${ }^{1}$

A juvenile waiver hearing is an individualized determination of whether jurisdiction over a given child should be ceded to adult criminal court. The juvenile court considers a wide variety of criteria in making this decision, including the child's age and criminal history, the severity of the offense, and the likelihood of successful rehabilitation in the juvenile justice system. In seeking waiver, the state often attempts to introduce a juvenile's own statements as evidence of her maturity or unamenability to treatment in the juvenile system. However, the use of these statements, which range from confessions to police at the time of arrest to statements made at court-ordered psychiatric evaluations, threatens juveniles' Fifth Amendment privilege against self-incrimination.

While the Supreme Court has delineated the scope of the privilege against self-incrimination at adult criminal trials ${ }^{2}$ and at juvenile delinquency hearings, ${ }^{3}$ there has been no such resolu-

† A.B. 1992, Dartmouth College; J.D. Candidate 1995, The University of Chicago.

1 States use a variety of terms in reference to this process. While this Comment refers to the change in jurisdiction as waiver, it is also known as transfer, diversion, or certification.

2 See generally Fisher $v$ United States, 425 US 391 (1976) (Fifth Amendment does not protect against compelled document production when request is made to party's attorney); Schmerber $v$ California, 384 US 757 (1966) (compelled withdrawal of blood for blood-alcohol testing does not implicate Fifth Amendment); Griffin v California, 380 US 609 (1965) (Fifth Amendment prohibits state prosecutor's comments that defendant's silence suggests guilt); Hoffman $v$ United States, 341 US 479 (1951) (extending Fifth Amendment privilege to answers that are merely links in an incriminating chain of evidence).

${ }^{3}$ See In re Gault, 387 US 1 (1967) (noting that privilege against self-incrimination should be applicable to juveniles as well as adults). 
tion in the context of juvenile waiver hearings. State supreme courts remain divided, and the few federal courts considering the issue have struggled over it as well. ${ }^{4}$

Many courts find that the Fifth Amendment privilege does not apply at the waiver hearing because the hearing is not a determination of guilt or innocence, but merely a choice of forum. These courts often emphasize the need for maximum discretion at juvenile waiver hearings. Other courts hold that the severe consequences of juvenile waiver hearings entitle juveniles to this important constitutional safeguard.

This Comment examines whether the privilege against selfincrimination should extend to the juvenile waiver hearing to prohibit the use of coerced or involuntary statements as evidence to support a juvenile's transfer to adult court. Although many state courts, and a few lower federal courts, have considered selfincrimination at the waiver hearing, none to date has articulated a coherent approach to this issue. This Comment places the issue within the context of juvenile justice and Fifth Amendment jurisprudence and introduces a two-tiered organizing principle for addressing self-incrimination issues at juvenile waiver hearings.

Section I explores the foundational principles of the juvenile justice system, the procedure of waiver hearings, and the constitutional protections currently afforded to juveniles. Section II describes the scope of, and the justifications for, the Fifth Amendment privilege against self-incrimination and examines how self-incrimination issues arise in the waiver context. Section III presents the reasoning various courts have employed in either accepting or rejecting the application of the privilege to juvenile waiver hearings. Finally, Section IV, applying a two-tiered approach for evaluating juvenile waiver cases, concludes that the privilege against self-incrimination must apply fully to the waiver hearing.

\footnotetext{
4 Federal courts adjudicate relatively few juvenile cases because, with the exception of crimes of violence and selected drug crimes, federal law requires that juveniles be tried in state courts whenever possible. 18 USC $\$ 5032$ (1988 \& Supp 1991). The federal waiver statute is substantially similar to most state waiver statutes. The analysis and the organizing principle suggested by this Comment apply equally to both federal and state cases.
} 


\section{THE JUVENILE JUSTICE SYSTEM AND THE DOCTRINE OF WATVER}

The history of juvenile justice in America reflects a persistent tension between the goal of preserving a unique legal forum for juveniles and the need to provide juveniles with procedural protections. Juvenile court systems have traditionally granted judges almost total discretion in the treatment and rehabilitation of juveniles, with little concern for due process or procedural regularity. However, many procedural protections have been extended to juveniles since the late 1960s.

\section{A. Foundational Principles of the Juvenile Courts}

The first juvenile court in the United States was established in 1899 in Cook County, Illinois. ${ }^{5}$ Prior to that time, juveniles accused of crimes were tried in adult courts. The impetus for separate juvenile jurisdiction grew out of the efforts of Progressive reformers seeking to improve the treatment of juveniles in the legal system. ${ }^{6}$ Progressives believed that children were physically, mentally, and morally different from adults. These reformers argued that children, as nascent moral beings, should be treated and rehabilitated by a separate, nurturing judicial system. ${ }^{7}$

The juvenile justice system has philosophical roots in the doctrine of parens patriae - the parental power of the state. ${ }^{8}$ This theory holds that it is the state's responsibility to care for the vulnerable, including juveniles and all others who are unable to care for themselves. Juvenile courts exercise jurisdiction over abused and neglected children as well as those facing criminal charges; ${ }^{9}$ thus, juvenile delinquency courts are considered civil

- Samuel M. Davis, Rights of Juveniles: The Juvenile Justice System $\$ 1.1$ at 1-1 (Clark Boardman Callaghan, 2d ed 1994). See also Robert M. Mennel, Thorns and Thistles: Juvenile Delinquents in the United States, 1825-1940 124-57 (New England, 1973) (tracing the nationwide development of juvenile courts in the early twentieth century).

6 Martin L. Forst and Martha-Elin Blomquist, Cracking Down on Juveniles: The Changing Ideology of Youth Corrections, 5 Notre Dame J L Ethics \& Pub Policy 323, 324 (1991).

7 For an overview of the role of Progressives in the development of the juvenile justice system, see generally Mennel, Thorns and Thistles; Anthony M. Platt, The Child Savers: The Invention of Delinquency (Chicago, 2d ed 1977).

${ }^{8}$ For a discussion of the origins of the parens patriae doctrine and its application in juvenile court, see generally Douglas R. Rendleman, Parens Patriae: From Chancery to Juvenile Court, 23 SC L Rev 205 (1971); Neil Howard Cogan, Juvenile Law, Before and After the Entrance of "Parens Patriae", 22 SC L Rev 147 (1970). (1991).

9 Barry C. Feld, The Transformation of the Juvenile Court, 75 Minn L Rev 691, 695 
courts because they purport to protect rather than punish children.

Traditionally, juvenile "criminal" cases were disposed of in accordance with a rehabilitative theory of punishment rather than theories of retribution or deterrence..$^{10}$ Judges served as the state's guardians over young criminals and assumed responsibility for their protection and moral development. Through benevolent intervention, the judge was to seek an appropriate balance between the best interests of the child and the interests of the state. ${ }^{11}$

Historically, juvenile court procedures were extremely informal so as not to intimidate young offenders. Judges were given great discretion over the disposition of juvenile cases so that they could deal individually with each child's developmental difficulty. ${ }^{12}$ The rules of evidence were suspended, and judge, lawyer, and juvenile conversed freely about the appropriate resolution. Juvenile courts employed modified, less formal procedures in adjudicating juvenile criminal cases at these "delinquency proceedings." ${ }^{13}$ Courts viewed a child's crime merely as evidence of her real needs, offering benevolent guidance and indeterminate sentences in reformatories to cure these troubled youths. ${ }^{14}$

\section{B. The Doctrine of Waiver}

Waiver of juveniles to the adult criminal justice system is a well-established practice. Most statutory schemes provide for waiver of older children or children who have committed serious crimes. Supporters of these schemes argue that waiver preserves the "rehabilitative" functions of the juvenile system while placing serious offenders under the jurisdiction of the punitive adult courts. ${ }^{15}$

Waiver principally occurs through three mechanisms: legislative or "automatic" waiver, prosecutorial waiver, and judicial

10 See Charles H. Whitebread and Robert Batey, The Role of Waiver in the Juvenile Court: Questions of Philosophy and Function, in John C. Hall, et al, eds, Major Issues in Juvenile Justice Information and Training: Readings in Public Policy 207, 208 (Academy for Contemporary Problems, 1981).

11 Platt, The Child Savers at 137-38 (cited in note 7).

12 Forst and Blomquist, 5 Notre Dame J I Ethics \& Pub Policy at 326 (cited in note 6). See also Feld, 75 Minn L Rev at 695 (cited in note 9); Mennel, Thorns and Thistles at 133-36 (cited in note 5).

${ }_{13}$ Davis, Rights of Juveniles $\S 1.2$ at 1-3 (cited in note 5).

14 Feld, 75 Minn L Rev at 695 (cited in note 9).

15 Forst and Blomquist, 5 Notre Dame J L Ethics \& Pub Policy at 334 (cited in note 6). 
waiver. No state operates exclusively under one scheme; often the same state will use all three waiver procedures, depending upon the seriousness of the offense and the juvenile's age. For example, a state might mandate legislative waiver for juveniles suspected of murder, permit prosecutors to choose the forum for children over age thirteen charged with rape, and require waiver by judicial hearing for all juveniles accused of aggravated assault.

Legislative waiver imposes statutory restrictions on the jurisdiction of juvenile courts, requiring the automatic transfer of juveniles accused of certain serious felonies to adult criminal court. ${ }^{16}$ Prosecutorial waiver statutes establish concurrent jurisdiction over certain offenses in both juvenile and adult criminal court, granting prosecutors the discretion to pursue a case in either forum. ${ }^{17}$

However, judicial waiver is the primary mechanism by which juveniles are transferred to the adult criminal justice system. ${ }^{18}$ In 1988, forty-eight states provided for some form of waiver by judicial hearing. ${ }^{19}$ While the exact procedures vary from state to state, most waiver hearings are bifurcated proceedings. ${ }^{20}$ First, the juvenile court judge holds a probable cause hearing in which the state must show that it is more likely than not that the juvenile committed the crime. If probable cause is established, the hearing progresses to its second stage, known as the dispositional

16 Twenty-three states and the District of Columbia have statutory waiver provisions that exclude certain offenses from the juvenile courts. The offenses commonly removed from juvenile jurisdiction include various degrees of criminal homicide, rape, kidnapping, burglary, and armed robbery. See Barry C. Feld, The Juvenile Court Meets the Principle of the Offense: Legislative Changes in Juvenile Waiver Statutes, $78 \mathrm{~J}$ Crim L \& Criminol 471, 511-15 (1987); Dean J. Champion and G. Larry Mays, Transferring Juveniles to Criminal Courts: Trends and Implications for Criminal Justice 70-71 (Praeger, 1991). For examples of legislative waiver statutes, see Ind Code Ann § 31-6-2-1.1(d) (West 1979 \& Supp 1994); La Children's Code Ann, Art 305(A)-(B) (West 1994); NC Gen Stat § 7A-608 (1989).

${ }_{17}$ Champion and Mays, Transferring Juveniles at 70-72. Although Nebraska appears to be the only state using concurrent jurisdiction as the exclusive means of waiver, at least nine states and the District of Columbia use concurrent jurisdiction as a means of waiver for particular crimes or for youths above a certain minimum age. See Davis, Rights of Juveniles $\$ 2.12$ at 2-25 to 2-26 nn 80-81, § 4.1 at 4-2 n 3 (cited in note 5). For examples of concurrent jurisdiction statutes see Ark Code Ann § 9-27-318(b)-(c) (Michie 1993); Fla Stat Ann § 39.022(5)(c) (West Supp 1991); Neb Rev Stat § 43-247 (1984).

${ }_{18}$ Recent legislative initiatives, however, suggest that many jurisdictions are beginning to favor automatic waiver based on the offense charged. See Janet E. Ainsworth, ReImagining Childhood and Reconstructing the Legal Order: The Case for Abolishing the Juvenile Court, 69 NC L Rev 1083, 1111 n 177 (1991).

19 See Champion and Mays, Transferring Juveniles at 68.

20 For examples of statutes requiring bifurcated hearings, see Mich Comp Laws Ann § 712A.4 (West 1993); Mass Ann Laws ch 119, § 61 (Law Co-op 1994). 
phase, where the judge determines whether the juvenile should be transferred to adult criminal court.

The criteria for waiver also vary among the states, but typically they include such factors as the juvenile's age, ${ }^{21}$ criminal record and history, and sophistication and maturity, as well as the seriousness of the alleged offense $\mathrm{e}^{22}$ and the juvenile's likelihood of rehabilitation or amenability to treatment. ${ }^{23}$ In waiver hearings, juvenile court judges rely on psychiatrists' evaluations of the juvenile and witnesses' statements about the child's character. Judges use their discretion to determine whether a transfer to adult criminal court would be in the best interests of the child and the community. ${ }^{24}$

\section{The Stakes of a Juvenile Waiver Hearing}

Throughout the United States, juvenile courts in 1991 waived an estimated 9,700 delinquency cases to adult criminal court by judicial waiver-a 21 percent increase over $1990 .{ }^{25}$ In

21 The minimum age at which juveniles may be transferred to criminal court by judicial waiver varies greatly. Currently at least ten states provide no minimum age; nine set the absolute minimum age at sixteen, see, for example, Hawaii Rev Stat \$ 571-22(a), (c) (1985 \& Supp 1992); nine set the age at fifteen, see, for example, La Children's Code Ann, Art 305(A)-(D); seventeen set the age at fourteen, see, for example, Colo Rev Stat Ann \& 19-2-806(1) (West 1990 \& Supp 1992); three set the age at thirteen, see, for example, Ga Code Ann § 15-11-39(a)(4) (Michie 1994); one sets the age at twelve, see Mont Code Ann § 41-5-206(1)(a) (1993); and one sets the age at ten, see 33 Vt Stat Ann § 5506(a) (Equity 1991). See also Champion and Mays, Transferring Juveniles at 67 (cited in note 16); Davis, Rights of Juveniles app B at B-1 (cited in note 5).

22 Factors considered here include the level of offense charged, the aggressiveness or violence with which the offense was committed, and whether the offense was committed against a person or against property. See, for example, Ind Code Ann § 31-6-2-4(b) (West 1979 \& Supp 1994).

23 See Davis, Rights of Juveniles $\S 4.3$ at 4-20 (cited in note 5), citing The President's Commission on Law Enforcement and the Administration of Justice, Task Force Report: Juvenile Delinquency and Youth Crime app B at 78 table 5 (1967). A survey of 207 juvenile courts showed that the juvenile's past history and the gravity of the offense were the factors weighing most heavily in the waiver decision. Id. Other factors included the juvenile's sophistication and maturity and the premeditation or violent nature of the crime. For a more complete list of the waiver criteria various courts employ, see Kent $v$ United States, 383 US 541, 565-68 (1966) (appendix listing determinative factors courts should consider at waiver hearings). See also Davis, Rights of Juveniles $\$ 4.3$ at 4-19 to 420 (cited in note 5).

24 The standard of proof appropriate for a waiver hearing is a subject of much dispute. While some states require "clear and convincing evidence" that the child is not amenable to treatment, others require merely a "fair preponderance of the evidence" or "substantial evidence" that the child cannot be rehabilitated by the juvenile justice system. See Champion and Mays, Transferring Juveniles at 65-67 (cited in note 16).

25 Jeffrey A. Butts, et al, eds, Juvenile Court Statistics 1991 12, 55 (National Center for Juvenile Justice, 1994). Delinquency cases may also reach adult criminal court via 
fact, the total number of delinquency cases transferred to adult court by judicial waiver increased 39 percent between 1987 and $1991 .{ }^{26}$ Waiver has become an increasingly popular method of handling youths accused of crime, particularly repeat offenders or those charged with violent crimes.

Children who are transferred to adult criminal courts are exposed to significant risks and penalties, including the loss of the rehabilitative services of the juvenile system, lengthy periods of pretrial detention, and the increased likelihood of conviction and a more severe sentence. While many believe that waiver hearings merely determine the appropriate forum, this view does not adequately consider the serious consequences of a waiver decision.

\section{Rehabilitation vs. punishment.}

In Kent $v$ United States, the Supreme Court described the waiver hearing as a "critically important" proceeding for juvenile defendants. ${ }^{27}$ The hearing itself determines whether a juvenile will be tried in the primarily rehabilitative juvenile system or in the primarily punitive adult criminal justice system. The differences in the goals of the two systems translate into serious consequences for juvenile offenders transferred out of juvenile court.

While "conviction" in the juvenile justice system leads to counseling, treatment, or a term of confinement in a reformatory (at worst), those convicted in the adult system are often incarcerated in adult prison facilities, which typically offer limited educational opportunities and fewer treatment and counseling alternatives. ${ }^{28}$ In Kent, the Court summarized the crucial differences between adult criminal courts and juvenile delinquency proceedings:

prosecutorial transfer. See Howard N. Snyder, et al, eds, Juvenile Court Statistics 19886 (National Center for Juvenile Justice, 1990) (noting approximately twelve thousand delinquency cases in 1988 waived to adult criminal court by judicial waiver and prosecutorial transfer combined). The National Center for Juvenile Justice no longer reports the number of cases reaching adult criminal court by prosecutorial transfer. See Butts, et al, eds, Juvenile Court Statistics 1991 at 4.

${ }_{26}$ Butts, et al, eds, Juvenile Court Statistics 1991 at 12 (cited in note 25).

27383 US 541, 556 (1966).

${ }^{28}$ The Fourth Circuit noted the serious consequences of a waiver decision: "By deciding the waiver issue, the juvenile court determines whether the accused, if found guilty, will receive nonpunitive rehabilitation as a juvenile from the state's social service agencies or will be sentenced as an adult." Kemplen $v$ Maryland, 428 F2d 169, 173-74 (4th Cir 1970). 
[The juvenile] may be confined, but with rare exceptions he may not be jailed along with adults. He may be detained, but only until he is 21 years of age. The court is admonished by the [D.C. juvenile] statute to give preference to retaining the child in the custody of his parents "unless his welfare and the safety and protection of the public cannot be adequately safeguarded"... The child is protected against consequences of adult conviction such as the loss of civil rights, the use of adjudication against him in subsequent proceedings, and disqualification for public employment. ${ }^{29}$

The significance of the disparity is further illustrated by a Seventh Circuit case that dramatically displayed the potential costs of waiver to a juvenile defendant: for the child in that case, waiver out of the juvenile system meant the difference between longterm psychiatric counseling as a juvenile and the mere four days of hospitalization the child did receive in the adult criminal justice system. ${ }^{30}$

Waiver also denies children the special immunities of juvenile status. For example, the trial records of juvenile cases are kept confidential, but adult criminal trials are matters of public record. ${ }^{31}$ Furthermore, while most juvenile courts retain jurisdiction over juveniles only until age twenty-one, the potential reach of an adult criminal sentence is essentially limitless. ${ }^{32}$ Finally, juvenile records are routinely expunged once children attain the age of majority, ${ }^{33}$ but juveniles convicted in adult court are saddled with a permanent felony record.

\section{Pretrial incarceration and conditions of confinement.}

While the waiver hearing itself imposes no sentence upon juveniles, the decision to transfer the juvenile to the adult court system does increase the likelihood of extended incarceration. Because the adult criminal justice system has more procedural requirements, many juveniles waived to adult criminal courts

29383 US at 556-57, quoting DC Code $\S 11-915(3)$ (1961).

30 Geboy $v$ Gray, 471 F2d 575, 578 (7th Cir 1973). A Fourth Circuit case addressing waiver under the Federal Juvenile Delinquency Act, 18 USC $\$ \S 5031-42$ (1988), also contrasts the rehabilitative benefits of the juvenile system with the stigma of criminal conviction. See United States v Hill, 538 F2d 1072, 1074 (4th Cir 1976).

${ }^{31}$ Kent, 383 US at 556.

${ }^{32}$ Id at 556-57.

${ }^{33}$ See Samuel M. Davis, Legal and Procedural Issues Related to the Waiver Process, in John C. Hall, et al, eds, Major Issues in Juvenile Justice Information and Training: Readings in Public Policy 227, 238-39 (Academy for Contemporary Problems, 1981). 
must endure periods of pretrial detention in adult lock-up facilities. ${ }^{34}$ For transferred juveniles, this delay can be considerable: one empirical study reported that it takes 2.5 times as long for a violent youth to be transferred, convicted, and sentenced in adult criminal court than to be considered for transfer, retained, "judged," and disposed of in juvenile court. ${ }^{35}$

This extended pre-trial processing and incarceration raises questions of fairness, due process, and the right to treatment for "transferred-but-not-convicted" juveniles. ${ }^{36}$ The problem of lengthy confinement is compounded by the harmful conditions that result from the incarceration of juveniles side by side with adults awaiting trial. One study reveals that juveniles held in adult jails have a suicide rate nearly five times greater than that of children in juvenile facilities. ${ }^{37}$ Physical conditions in adult jails provide few recreational opportunities, no educational opportunities, and almost no privacy to detainees. Furthermore, there is little classification of inmates in these facilities, so a juvenile detainee with no prior record may be forced to share a cell with dangerous adult offenders. Limited funding and overcrowding result in dangerous and volatile conditions for inmates, particularly for uninitiated juvenile detainees. ${ }^{38}$

\section{More severe punishment.}

As noted in many court opinions and studies, juveniles frequently receive more severe punishment when waived to adult court. $^{39}$ In Commonwealth $v$ Wayne W., the Massachusetts Su-

34 See Cary Rudman, et al, Violent Youth in Adult Court: Process and Punishment, 32 Crime \& Delinq 75, 83 (1986); Barry C. Feld, Criminalizing Juvenile Justice: Rules of Procedure for the Juvenile Court, 69 Minn L Rev 141, 201 (1984).

${ }_{35}$ Rudman, et al, 32 Crime \& Delinq at 83.

${ }^{36}$ The characterization is Rudman's. See id at 93.

${ }^{37}$ See Feld, 69 Minn L Rev at 201 \& n 200, citing Michael G. Flaherty, An Assessment of the National Incidence of Juvenile Suicide in Adult Jails, Lockups, and Juvenile Detention Centers 10 table 1 (Community Research Forum, 1980).

${ }^{33}$ Human Rights Watch, Prison Conditions in the United States 18, 20-22 (1991).

39 Although a 1978 study found that juveniles waived to adult court received lesser sentences than those who remained in juvenile court, see Donna Hamparian, Juveniles in Adult Court, in National Institute for Juvenile Justice and Delinquency Prevention, Dealing with Serious, Repeat Juvenile Offenders 39, 42-43 (Department of Justice, 1982), more recent inquiries offer the opposite view. A study published in 1989, using data collected between 1978 and 1983, found that while juvenile property offenders received lighter sentences in adult court than they might have received in juvenile court, juveniles committing personal crimes received significantly more severe sentences in adult court than did like offenders in juvenile court. Carole Wolff Barnes and Randal S. Franz, Questionably Adult: Determinants and Effects of the Juvenile Waiver Decision, 6 Just Q 
preme Judicial Court observed that for a juvenile, the outcome of a murder case "will, in the event of conviction, usually mean the difference between a limited period of confinement in a treatment setting and a lengthy term of imprisonment. ${ }^{30}$ The Fourth Circuit also recognized the importance of this difference: "[I]t seems to us nothing can be more critical to the accused than determining whether there will be a guilt determining process in an adulttype criminal trial."41 Other writers note that "both the incidence and length of incarceration are far greater in the criminal courts-on the average, up to five times longer. ${ }^{\prime 42}$ Studies also indicate that such detention is a significant predictor of recidivism for youths. ${ }^{43}$

The Supreme Court has also acknowledged the potentially severe consequences of waiver. In Kent, the Court stated that the "decision as to waiver of jurisdiction ... was potentially as important" to the juvenile in that case "as the difference between five years' confinement and a death sentence... ." ${ }^{\text {"4 }}$ In certain jurisdictions, juveniles waived to adult court face the possibility of the death penalty - a sentencing alternative unavailable to a juvenile court judge. ${ }^{45}$

The increased severity of punishment for juveniles convicted in adult court should come as no surprise. Indeed, one of the mantras of the current movement to try more juveniles as adults is that juvenile offenders should pay an adult penalty for an adult crime. ${ }^{46}$ Although the wisdom of this policy is fiercely contested, both sides seem to agree: transfer to adult court carries serious consequences (for children accused of crimes).

117,133 (1989).

40414 Mass 218, 606 NE2d 1323, 1330 (1993). See also Geboy v Gray, 471 F2d 575, 578 (7th Cir 1973) (noting that "[i]nstead of a maximum period of detention of approximately four years, at which time petitioner would have reached the age of twenty-one, he was convicted of two felony charges and given an eighteen year sentence in the state penitentiary").

41 Kemplen $v$ Maryland, 428 F2d 169, 174 (4th Cir 1970) (emphasis omitted).

42 Rudman, et al, 32 Crime \& Delinq at 92 (cited in note 34 ).

43 Id.

44383 US at 557.

45 See, for example, La Children's Code Ann, Art 897-98 (West 1994) (sentencing options in juvenile court range from reprimand to commitment of juvenile by the Department of Corrections, but exclude a sentence of death).

${ }_{46}$ See, for example, George Papajohn, Adult or Juvenile? Suspects Await Fate, Chi Trib $\S 2$ at 1 (Jan 7, 1994); Robert F. Howe, Va. Panel Links Violent Crime, Rise in Juveniles Tried as Adults, Wash Post E3 (Nov 10, 1992); Eileen McNamara, Crime and Punishment, Boston Globe Mag 14 (Nov 24, 1991). 
D. Constitutional Rights of Juveniles: "The Essentials of Due Process and Fair Treatment"

Under the doctrine of parens patriae, juvenile courts were primarily concerned with the treatment of children and the protection of society. They paid little attention to constitutional safeguards. The courts operated informally, granting juvenile judges the broad discretion thought necessary to effectively rehabilitate children, under the assumption that the interests of the child were synonymous with those of the state. Thus, although the juvenile system struggled to balance the judge's discretion with procedural protections for children, juveniles actually enjoyed very few such protections at delinquency or waiver proceedings.

Concerned with the discretionary nature of the system, critics began to push for reform of the juvenile courts in the 1960s. In response, the Supreme Court gradually modified traditional aspects of the system, extending certain adult criminal protections to children in the juvenile courts. ${ }^{47}$

In Kent, the Court addressed for the first and only time the constitutional protections due to juveniles at the waiver hearing. While recognizing the juvenile courts' unique objective "to provide measures of guidance and rehabilitation for the child and protection for society," the Kent Court declared that the juvenile courts' "admonition to function in a 'parental' relationship is not an invitation to procedural arbitrariness. ${ }^{\text {"48 }}$ Although the Court explicitly noted that juvenile hearings did not have to conform to the stringent procedural requirements of traditional criminal trials, the Court also stated unequivocally that such "hearing[s] must measure up to the essentials of due process and fair treatment." ${ }^{49}$ With this holding, Kent laid the foundation upon which all subsequent juvenile justice cases would stand. ${ }^{50}$ note 6).

47 Forst and Blomquist, 5 Notre Dame J L Ethics \& Pub Policy at 328-29 (cited in

48383 US at $554-55$.

49 Id at 562.

so Initially, the Kent holding was limited to the particular statutory language of the District of Columbia Juvenile Court Act, but it is now widely accepted that the principles stated in Kent have constitutional force. See Davis, Rights of Juveniles $\S 4.2$ at 4-9 (cited in note 5) ("[F]ollowing references to Kent in In re Gault, the weight of authority now favors the judgment that the principles stated in Kent are of constitutional dimensions."). See In re Gault, 387 US 1, 30-31 (1967) (treating the Kent principle as if of constitutional dimension in the context of juvenile delinquency proceedings). See also, for example, Powell $v$ Hocker, 453 F2d 652 (9th Cir 1971), overruled on other grounds, Harris $v$ Procunier, 498 F2d 576 (9th Cir 1974); United States $v$ Rundle, 438 F2d 839, 842 (3d Cir 
The following year, the Court in In re Gault again levelled strong criticism at the exercise of unbridled discretion in the juvenile courts, this time in the context of a delinquency proceeding rather than a waiver hearing. ${ }^{51}$ The Gault Court noted that "neither the Fourteenth Amendment nor the Bill of Rights is for adults alone," ${ }^{152}$ reiterating the holding of Kent that juvenile hearings must "measure up to the essentials of due process and fair treatment." ${ }^{93}$ Under this standard, the Court held that juveniles at delinquency proceedings are entitled to the right to notice of charges, the right to counsel, the right to confrontation and cross-examination of witnesses, and the privilege against self-incrimination. ${ }^{54}$

Perhaps even more significant than the specific rights extended to juveniles in Gault was the mode of analysis the Court employed to evaluate the procedural process that was extended. Rather than accepting the traditionally discretionary nature of juvenile hearings, the Court carefully considered the benefits and flaws of the juvenile justice system. ${ }^{55}$ In Gault, the Court took a candid look at the potential benefits of the juvenile justice system in light of the procedural protections at issue. Thus, in applying the Kent principle to determine which rights to extend to juveniles, the Court in essence balanced the significance of the procedural right against its interference with the traditional goals and practices of the juvenile court system. This approach fundamentally altered the way the Court addressed juveniles' claims for procedural protections. ${ }^{56}$

The first application of the Gault approach occurred in In re Winship, where the Court extended the reasonable doubt standard to juvenile delinquency hearings. ${ }^{57}$ In Winship, the Court weighed the importance of accurate fact-finding and the potential loss of liberty at stake against the extent to which proof beyond a

1971); Brown v Wainwright, 537 F2d 154, 155 n 1 (5th Cir 1976); Kelley v Kaiser, 992 F2d 1509, 1512-14 (10th Cir 1993); In re Harris, 67 Cal 2d 876, 64 Cal Rptr 319, 321-22

(1967); United States v E.K., 471 F Supp 924, 930 (D Or 1979).

${ }^{51} 387$ US 1, 16-22 (1967).

${ }^{52}$ Id at 13.

${ }_{63}$ Id at 30, quoting Kent, 383 US at 562.

54387 US at 33-34, 41, 55, 57. Justice Harlan wrote a strong dissent advocating a more limited approach to juveniles' fundamental due process rights. Harlan wanted to extend only three procedural protections: notice of charges, right to counsel, and maintenance of a written record. Id at 72 (Harlan concurring in the judgment and dissenting in part).

${ }_{55}$ Id at $27-30$.

${ }^{56}$ See Feld, 69 Minn L Rev at 141-42, 151-64 (cited in note 34).

57397 US 358 (1970). 
reasonable doubt might interfere with "the beneficial aspects of the juvenile process. ${ }^{.15}$ In assessing the first matter, the Court concluded that proof beyond a reasonable doubt is indeed important to accurate fact-finding in situations where juveniles face a significant loss of liberty. As for the second issue, the Court noted that the reasonable doubt standard would not detract from the informality, flexibility, or speed of the juvenile hearing, and would not alter the opportunity "for a wide-ranging review of the child's social history and for his individualized treatment."

In Breed $v$ Jones, the Court applied a Gault-type analysis to determine whether double jeopardy attached at juvenile delinquency proceedings. ${ }^{60}$ The Court concluded that the vital constitutional protection against double jeopardy would not "diminish flexibility and informality to the extent that those qualities relate uniquely to the goals of the juvenile-court system."

Post-Gault, the Court has refused to extend certain constitutional protections to juveniles in two contexts. In McKeiver $v$ Pennsylvania, the Court held that the right to a jury trial did not apply in juvenile proceedings. ${ }^{62}$ Though acknowledging the holding in Kent that juveniles are entitled to basic due process, the Court nevertheless found that extending the panoply of adult procedural protections would effectively eviscerate the discretionary character of juvenile court without increasing the reliability of the proceedings. ${ }^{63}$ In Schall $v$ Martin, the Court similarly rejected the claim that pretrial detention of juveniles offended the Due Process Clause of the Fourteenth Amendment. ${ }^{64}$

In both Winship and Gault, the Court specifically reserved the question of whether courts must balance constitutional rights against the unique character of the juvenile system when they consider extending procedural protections to the juvenile waiver

\footnotetext{
sB Id at 365-66.

59 Id at 366 .

60421 US 519 (1975).

61 Id at 535. See also id at $535 \mathrm{n}$ 15:
}

That the flexibility and informality of juvenile proceedings are diminished by the application of due process standards is not open to doubt. Due process standards inevitably produce such an effect, but that tells us no more than that the Constitution imposes burdens on the functioning of government and especially of law enforcement institutions.

62403 US 528, 545 (1971).

63 Id at 543-51.

64 467 US 253, 281 (1984). 
hearing. ${ }^{65}$ Thus, lower courts continue to struggle with this issue.

\section{The PRIVILEge against Self-INCRIMINATion AND ItS IMPLICATIONS AT THE JUVENILE WAIVER HEARING}

The Fifth Amendment privilege against self-incrimination holds a dubious place in the constitutional history of our nation. Although the privilege has been celebrated as the cornerstone of American liberty, numerous scholars, including John Wigmore, Jeremy Bentham, and Judge Henry Friendly, have criticized it as a procedural barrier to truth and justice. ${ }^{66}$ Nevertheless, the privilege itself endures, providing that "[n]o person ... . shall be compelled in any criminal case to be a witness against himself. ${ }^{n 7}$ In order to understand how the privilege against selfincrimination applies to the juvenile waiver hearing, one must first understand the scope and the justifications of the modern privilege.

\section{A. The Scope of the Privilege}

In 1964, the Court in Malloy $v$ Hogan held that the Fifth Amendment privilege against self-incrimination applied to the states because it was incorporated into the Due Process Clause of the Fourteenth Amendment. ${ }^{68}$ Although it is often characterized as a broad protection against government-compelled evidence, the privilege is actually subject to strict limitations. ${ }^{69}$

In order to receive Fifth Amendment protection, a statement must constitute a testimonial communication, be compelled, and incriminate the speaker in a criminal proceeding. ${ }^{70}$ First, the privilege only protects testimony of communicative value, not physical evidence such as blood or voice samples. ${ }^{71}$ Furthermore,

${ }_{65}$ Gault, 387 US at 13; Winship, 397 US at 359.

${ }^{66}$ See John H. Wigmore, Nemo Tenetur Seipsum Prodere, 5 Harv L Rev 71, 87 (1891); Jeremy Bentham, 3 Rationale of Judicial Evidence 131-48 (Garland, 1978); Henry J. Friendly, The Fifth Amendment Tomorraw, 37 U Cin L Rev 671, 680-81 (1968).

67 US Const, Amend V.

${ }^{68} 378$ US 1 (1964).

${ }^{69}$ Stephen J. Schulhofer, Some Kind Words for the Privilege Against Self-Incrimination, 26 Valp U L Rev 311, 313 (1991); Project, Twenty-Second Annual Review of Criminal Procedure: United States Supreme Court and Courts of Appeals 1991-1992, 81 Georgetown L J 853, 1371 (1993).

${ }_{70}$ See, for example, Fisher $v$ United States, 425 US 391, 409 (1976).

71 Schmerber v California, 384 US 757, 765 (1966); United States v Dionisio, 410 US 1,17 (1973). 
statements that are used merely as diagnostic tools or "verbal acts" are not considered testimonial because they are not intended to prove the truth of the matter asserted. Thus, such statements do not implicate the privilege. ${ }^{72}$ The privilege does apply, however, to all statements that are used as a source of factual information. ${ }^{73}$

Although the privilege applies only to compelled testimony, compulsion is not limited to statements or confessions "beaten" out of a witness. Rather, the privilege precludes admitting any statement procured without proper warnings ${ }^{74}$ or drawing an adverse inference from a witness's exercise of her privilege against self-incrimination. ${ }^{75}$

Finally, the privilege only protects against compelled testimony that tends to incriminate the witness in a criminal proceeding. The Court held in Hoffman $v$ United States that the privilege extends to civil proceedings only if that testimony could be used to incriminate the witness in a subsequent criminal proceeding. ${ }^{76}$ Evidence is incriminating when the witness has reasonable cause to believe that her answer would support a criminal conviction or provide a link in the chain of evidence leading to a conviction. ${ }^{77}$

\section{B. Justifications for the Privilege}

The policies supporting the privilege against self-incrimination are as controversial as the scope of the privilege itself. Although a full discussion of these justifications is beyond the scope of this Comment, it is important to mention those explanations that the Court has offered..$^{78}$ In many ways the privilege against self-incrimination is an "illustration of the coalescence of several goals within a single procedural right." ${ }^{m 9}$

Perhaps the most common justification for the privilege is the promotion of truth. In Murphy $v$ Waterfront Commission, the Court stated that the privilege grew from "our distrust of self-

72 Doe v United States, 487 US 201, 207 (1988).

73 Id at 213.

74 Miranda v Arizona, 384 US 436, 467-68 (1966).

75 Griffin v California, 380 US 609, 615 (1965).

${ }^{76} 341$ US $479,486-87$ (1951).

77 Id at 486 .

${ }^{78}$ For a comprehensive evaluation of the justifications for the privilege, see Schulhofer, 26 Valp U L Rev at 316-25 (cited in note 69).

79 Wayne R. LaFave and Jerold H. Israel, 1 Criminal Procedure $\S 1.6(\mathrm{j})$ at 43 (West, $2 d$ ed 1992). 
deprecatory statements." ${ }^{100}$ The Gault Court employed similar reasoning, holding that the privilege "related to the question of the safeguards necessary to assure that admissions or confessions are reasonably trustworthy, that they are not the mere fruits of fear or coercion, but are reliable expressions of the truth." explanation posits that authorities are more likely to receive truthful information when defendants have the freedom to remain silent.

Another justification for the privilege, in Justice Goldberg's words, is the "fear that self-incriminating statements will be elicited by inhumane treatment and abuses." ${ }^{.82}$ This justification harkens back to the Star Chamber and inquisitional systems of criminal justice. ${ }^{83}$ The fear of inhumane treatment, however, extends beyond traditional torture and bullying to include the equally cruel practice of imposing severe sanctions upon defendants for refusing to answer. ${ }^{84}$

The Court in Gault addressed a third purpose of the privilege that focuses on the balance between an individual's freedom and the state's obligation to produce evidence in its role as criminal prosecutor. According to the Gault Court, one of the fundamental purposes of the privilege is "to prevent the state, whether by force or by psychological domination, from overcoming the mind and will of the person under investigation and depriving him of the freedom to decide whether to assist the state in securing his conviction." ${ }^{85}$ In this sense the privilege safeguards against state encroachment upon individual freedom: it gives criminal defendants the option to either cooperate in the proceedings against them or hold the state to its burden of proof.

${ }^{80} 378$ US 52, 55 (1964). Justice Goldberg's opinion provides an extensive list of the goals and purposes behind the privilege, including preserving the witness's right to privacy. See id. For a compelling defense of the privacy foundations of the privilege, see Andresen $v$ Maryland, 427 US 463, 486-92 (1976) (Brennan dissenting). But see Schulhofer, 26 Valp U I Rev at 317-20 (cited in note 69), for a strong criticism of traditional justifications.

81387 US at 47.

82 Murphy, 378 US at 55.

83 See Mark Berger, Taking the Fifth: The Supreme Court and the Privilege Against Self-Incrimination 4-7 (DC Heath, 1980).

${ }^{84}$ See Griffin v California, 380 US 609, 614 (1965). See also Berger, Taking the Fifth at 31 .

85 387 US at 47. See also Culombe $v$ Connecticut, 367 US 568, 581-82 (1961) (The privilege is based on "the requirement that the State which proposes to convict and punish an individual produce the evidence against him by the independent labor of its officers, not by the simple, cruel expedient of forcing it from his own lips."). 


\section{Self-Incrimination at the Juvenile Waiver Hearing}

Self-incrimination issues usually arise at the juvenile waiver hearing in the assessment of the child's amenability to treatment. Of the factors employed in the waiver decision, this criterion is one of the most subjective and arguably the most difficult to assess. As a result, courts often attempt to rely on the juvenile's own statements in making their determination.

First, a juvenile's statements or confessions to police or other state authorities may be used to help assess the child's character, maturity, or sophistication. Although the privilege is not implicated by voluntary statements, self-incrimination issues arise if the statement is coerced or if it is made by the juvenile without knowledge of the consequences. ${ }^{86}$ Such coercion is of particular concern when juveniles are involved. Juveniles are generally more vulnerable than adults to intimidation and interrogation practices. Furthermore, juveniles are often incapable of understanding the significance of their right to silence. Indeed, several jurisdictions require the presence of a parent or guardian before a child may waive the privilige. ${ }^{87}$

Second, the court may order children to submit to psychiatric evaluations to determine their amenability to treatment within the juvenile justice system. Although these evaluations have a diagnostic component, they are frequently used to gather direct information about a defendant's social and personal history, criminal history, prior delinquency, and even the offense itself. ${ }^{88}$ Of course, some juveniles will refuse to comply with the court's order. However, the order itself may be coercive if the state is allowed to draw negative implications about the child's amenability to treatment from her refusal to submit to mandatory examinations. A court's use of such refusal as evidence of uncooperativeness and unwillingness to be rehabilitated presents many self-incrimination problems.

Among courts that agree that the privilege applies at the waiver hearing, some extend it only to inculpatory statements that may be used against a child at a later delinquency hearing or (if waiver is granted) an adult criminal proceeding. ${ }^{89}$ This

\footnotetext{
${ }^{86}$ Whether these practices constitute actual violations of the privilege is the issue this Comment attempts to resolve.

${ }^{87}$ See Davis, Legal and Procedural Issues at 227-31 (cited in note 33).

\&s See United States v J.D., 517 F Supp 69, 73-74 (S D NY 1981). These evaluations are a routine part of most discretionary judicial waiver schemes.

${ }_{89}$ See, for example, Christopher $P$. $v$ State, 112 NM 416, 816 P2d 485, 489 (1991);
} 
position, however, merely protects the juvenile from being forced to incriminate herself in subsequent adjudicatory proceedings-a right clearly mandated by the Supreme Court in Gault. ${ }^{90}$ Other courts take the position, advocated in this Comment, that the privilege against self-incrimination protects juveniles from the use of all coerced confessions, mandatory psychiatric examinations, or refusals to testify or submit to exams as evidence supporting waiver to adult court. ${ }^{91}$

\section{JUDICIAL TREATMENT OF THE ISSUE}

State supreme courts have long differed over whether the privilege against self-incrimination protects juveniles against compelled statements that provide evidence in support of waiver. Regardless of their conclusions, courts seem to approach the issue in terms of either fundamental due process rights or Fifth Amendment jurisprudence.

\section{A. Denial of the Privilege at the Waiver Hearing}

Courts have employed three primary rationales to deny the privilege at the juvenile waiver hearing: (1) because juvenile courts are not constitutionally mandated, they can freely limit juveniles' procedural protections; (2) the privilege is not necessary to secure due process; and (3) the statements to which the privilege would apply are not incriminating.

First, courts have held that the privilege against self-incrimination cannot apply to the waiver hearing because there is no "constitutional right to be treated as a juvenile." ${ }^{\text {"T2 }}$ They maintain that since the state is not constitutionally required to have juvenile courts, it has a legitimate right to rescind the privilege

People $v$ Hana, 443 Mich 202, 504 NW2d 166, 177 (1993), cert denied as Hana $v$ Michigan, 114 S Ct 1074 (1994).

so 387 US at $49-55$.

${ }^{91}$ See R.H. $v$ State, 777 P2d 204 (Alaska App 1989) (holding that court order compelling juvenile to submit to psychiatric evaluation to determine his amenability to treatment as minor violated his privilege against self incrimination); Edwards $v$ State, 227 Kan 723, 608 P2d 1006, 1009 (1980) (holding that self-incriminating statements that are inadmissible at juvenile delinquency hearing are also inadmissible at waiver proceeding); Wayne W., $606 \mathrm{NE2d}$ at 1331 (holding that juvenile ordered to submit to mandatory psychiatric evaluation for waiver hearing is protected by privilege against self-incrimination); J.T.P. v State, 544 P2d 1270 (Okla Crim App 1975) (holding that privilege prohibits state from admitting coerced confessions into evidence at juvenile waiver hearing).

${ }^{92}$ People $v$ Hana, 443 Mich 202, 504 NW2d 166, 175 (1993), cert denied as Hana $v$ Michigan, 114 S Ct 1074 (1994). 
of juvenile jurisdiction. ${ }^{93}$ Under this view, the right to rescind jurisdiction includes the right to determine which procedural protections apply at a waiver hearing.

A second rationale is that the privilege is not part of the fundamental due process required at waiver hearings. This reasoning, followed by the courts in such states as Illinois, Michigan, Washington, and New York, relies on the ruling in Kent that waiver proceedings need only comport with requirements of basic fairness and due process. ${ }^{94}$ These courts support their position by emphasizing the great burden that the privilege places upon states attempting to assess juveniles' amenability to treatment..$^{95}$

Courts employing this second rationale further reason that the privilege poses an excessive burden on the courts by denying the use of psychiatric evaluations, which can be valuable tools for assessing amenability to treatment. ${ }^{96}$ Some courts emphasize the administrative inconvenience and potential loss of discretion that the application of the privilege entails. They conclude that the state's purpose "may best be effectuated by the sound exercise of the juvenile court judge's discretion ... limited of course by the general requirements of due process and fair treatment, but not governed by the strict rules of procedure ...."97 This evaluation of the interests involved resembles the Gault analysis because it balances the interests of the state against the importance of the procedural right at issue. ${ }^{98}$ However, labelling the privilege a "strict rule of procedure" ignores the protection the privilege may provide juveniles in that forum. ${ }^{99}$

Some courts employ a third rationale that statements increasing the likelihood of waiver do not fall within the scope of the privilege. Courts denying the scope of the privilege most frequently do so on the grounds that the juvenile's statements are not "incriminating." These courts reason that the "[waiver] proceeding is not an adjudication of the child's guilt or innocence

30 Hana, 504 NW2d at 175.

94 See id at 174; People v Taylor, 76 Ill 2d 289, 391 NE2d 366, 372-73 (1979); State $v$ Piche, 74 Wash 2d 9, 442 P2d 632, 636 (1968); In re Jose D., 66 NY2d 638, 485 NE2d 1025, 1026 (1985). 36.

95 See Taylor, 391 NE2d at 372-73; Hana, 504 NW2d at 178; Piche, 442 P2d at 635(1981).

5e See, for example, Commonwealth $v$ Dotson, 286 Pa Super 595, 429 A2d 682, 684

57 Taylor, 391 NE2d at 372, quoting Piche, 442 P2d at 635-36 (emphasis added).

${ }_{98}$ See text accompanying notes 51-65.

s9 See text accompanying notes 25-46. 
and, therefore, the child's Fifth Amendment rights are not in issue."100 They therefore conclude that the waiver hearing poses no direct penalty to the juvenile because it merely determines the appropriate forum for the case. ${ }^{101}$ As one court observed, "[t]he psychological evaluation is not [ ] conducted for use at the adjudication hearing to determine the child's guilt or innocence of the crime charged, but as an aid to the court in its determination of amenability to treatment in the juvenile system."102 Under this logic, juveniles are sufficiently protected if their privilege against self-incrimination is fully enforced during their subsequent criminal trial or delinquency hearing. ${ }^{103}$

In presenting their position, these courts provide only the most cursory Fifth Amendment analysis. They imply that unless there is a direct risk of incrimination at a proceeding which determines guilt or innocence, the privilege against self-incrimination does not apply. They fail to recognize that protecting juveniles against use of compelled statements in a subsequent adult criminal proceeding is not equivalent to protecting them from the use of their statements to "incriminate" them in the waiver hearing itself.

\section{B. Applying the Privilege to the Waiver Hearing}

Several courts have extended the privilege to the juvenile waiver hearing on the ground that the privilege prohibits the state from using a juvenile's compelled statements as evidence supporting waiver to the adult court system. State and federal courts reaching this conclusion fall roughly into two categories: those that base their rulings on the Kent principle of fundamental due process, and those that reason in terms of the scope of the privilege against self-incrimination.

${ }^{100}$ K.W.M. $v$ State, 598 SW2d 660, 662 (Tex 1980).

101 See, for example, id; C.J.P. v State, 650 SW2d 465, 466-67 (Tex 1983); State in Interest of Bruno, 388 S2d 784, 787 (La 1980). But compare Christopher $P$. $v$ State, 112 NM 416, 816 P2d 485, 488-89 (1991); Appeal in Pima County, 139 Ariz 446, 679 P2d 92, 95-96 (1984). Pima County and Christopher $P$. each apply the privilege to the waiver hearing but limit their holdings to the facts of the case. Both courts hold that the scope of the privilege would not protect the juvenile if questioning was "appropriately limited."

102 Bruno, $388 \mathrm{~S} 2 \mathrm{~d}$ at 787.

103 See Christopher P., 816 P2d at 489; Pima County, 679 P2d at 95. 
1. Courts extending the privilege under a fundamental due process argument.

The Kent Court held that a juvenile waiver hearing "assumes procedural regularity sufficient in the particular circumstances to satisfy the basic requirements of due process and fairness." 104 Almost thirty years later, this holding continues to dictate the procedural protections to which juveniles are entitled. Some courts maintain that the privilege applies to the waiver hearing because it is part of essential fairness and basic due process. ${ }^{105}$ These courts acknowledge the critical consequences of the waiver hearing and emphasize the fundamental protections the privilege extends to juveniles. For example, the Southern District of New York held that "[juvenile] liberty is . . . very much at stake [at a waiver hearing]. Withholding Fifth Amendment protection from these defendants during this stage of these proceedings would deprive them of the freedom to choose whether to assist the state."106

Similarly, courts find that the privilege is essential to due process and fairness because it promotes accurate fact-finding, thereby protecting juveniles from government coercion and oppression at the waiver hearing. One such court held: "[W]e believe it to be contrary to the fundamental policy of the juvenile court system to permit a child within its jurisdiction to stand trial as an adult with no consideration of whether an admission or confession obtained from him was taken under circumstances which make its trustworthiness suspect." 107

2. Cases holding that statements at the waiver hearing fall within the scope of the privilege.

Other courts applying the privilege at the waiver hearing speak in terms of Fifth Amendment jurisprudence. They emphasize that evidence used to support waiver is incriminating be-

${ }^{104} 383$ US at 553.

${ }^{265}$ See, for example, J.T.P. v State, 544 P2d 1270, 1276 (Okla Crim App 1975).

106 United States v J.D., 517 F Supp 69, 71 (S D NY 1981).

107 J.T.P., 544 P2d at 1276. See also State v Y.B., 264 NJ Super 423, 624 A2d 1038, 1041 (1993), rev'd on other grounds, In the Interest of A.L., 271 NJ Super 192, 638 A2d 814 (1994) (holding that privilege is violated when court requires juvenile to admit wrongdoing to be eligible to receive benefits of rehabilitation and juvenile court adjudication); Wayne W., $606 \mathrm{NE} 2 \mathrm{~d}$ at 1329 (holding that privilege applies to juvenile transfer proceedings unless juveniles voluntarily choose to offer independent psychiatric evidence). 
cause it provides a link in the chain necessary to prosecute children in adult criminal court.

The Court of Appeals of Alaska, for example, concluded through this analysis that the privilege prohibits mandatory psychiatric examinations at waiver hearings: "[J]uvenile waiver proceedings [cannot] realistically be said to affect 'only the forum where the issue of guilt will be adjudicated.' A juvenile waiver proceeding is the only available avenue by which the state may seek to prosecute a child as an adult." 108 The Southern District of New York also found the waiver hearing to be "the essential preliminary step in any criminal prosecution of the juvenile."109

Some courts take the slightly different position that the privilege against self-incrimination must apply because the potential results of the proceeding pose a sufficient risk of adverse consequences to the participants. These courts emphasize the punitive intent of the adult criminal justice system: "The consequences to the juvenile of the court's decision to permit him to be tried as an adult may be tremendous .... We have recognized that such a decision may be the most severe sanction the Juvenile Court can impose."110 In keeping with this view, such courts reject the characterization of the waiver hearing as a neutral proceeding designed to assess the best interests of both the juvenile and society; ${ }^{111}$ they point out that the state is seeking waiver and the child is opposing it. ${ }^{112}$

Other courts consider waiver to be the "ultimate punishment" of the juvenile justice system, relying on the Supreme Court's ruling in Estelle $v$ Smith $^{113}$ to extend the privilege to the waiver hearing. ${ }^{114}$ In Estelle, the Court held that it is a violation of a defendant's privilege against self-incrimination to admit at the sentencing phase of a capital felony trial a psychiatrist's testimony assessing the defendant's future dangerousness, when the defendant did not have the opportunity to refuse the psychiatric exam. ${ }^{115}$ Most significantly, the Court found no basis for distinguishing between the trial and penalty

${ }^{108}$ R.H. $v$ State, 777 P2d 204, 210 (Alaska App 1989).

${ }_{109}$ United States $v$ J.D., 517 F Supp 69, 71 n 2 (S D NY 1981), quoting United States $v$ E.K., 471 F Supp 924, 929 (D Or 1979).

${ }_{110}$ J.T.P. v State, 544 P2d 1270, 1275 (Okla Crim App 1975).

211 R.H., 777 P2d at 211.

112 Wayne W., $606 \mathrm{NE} 2 \mathrm{~d}$ at 1330.

113451 US 454 (1981).

114 See Wayne W., 606 NE2d at 1330; R.H., 777 P2d at 208-09.

115451 US at $461-69$. 
phases: "Given the gravity of the decision to be made ..., the State is not relieved of the obligation to observe fundamental constitutional guarantees."116

Courts construe Estelle to prohibit the state from using compelled psychiatric evaluations to prove defendants' future dangerousness. ${ }^{117}$ Some state supreme courts, believing that waiver is indeed the "ultimate punishment" of the juvenile justice system, maintain that to refuse to extend Estelle in this context is to ignore the true consequences of the waiver hearing: ${ }^{118}$ "a sentencing decision that represents a choice between the punitive disposition of adult criminal court and the 'rehabilitative' disposition of the juvenile court."119

\section{Why THE PRIVILEGE AGAINST SELF-INCRIMINATION MUST EXTEND TO THE JUVENILE WAIVER HEARING}

Although several courts have considered whether the privilege against self-incrimination should protect juveniles at the waiver hearing, none has articulated a coherent approach to this question. The confusion in this area can be seen in the fact that courts both denying and extending the privilege have spoken in terms of Kent's fundamental due process argument or the scope of the Fifth Amendment privilege. Neither argument alone, however, is sufficient to justify extending the privilege to the waiver hearing. Courts must develop an organizing principle that unites these two prevailing legal doctrines.

This Comment proposes a two-tiered approach to the problem, incorporating both juvenile case law and Fifth Amendment jurisprudence. It proposes that the privilege against self-incrimination be extended to the juvenile waiver hearing. Under the proposed analysis, the privilege should apply because the right not to incriminate oneself is a component of the fundamental fairness

\footnotetext{
116 Id at 463.

117 See Jones $v$ Cardwell, 686 F2d 754, 756 (9th Cir 1982) (holding that Estelle's reasoning should apply to cases "involv[ing] statements and admissions by an incarcerated defendant to an individual acting on behalf of the state that exposed the defendant to serious consequences") (emphasis added). But see In re Jose D., 66 NY2d 638, 485 NE2d 1025, 1026-27 (1985) (holding that Estelle "has been limited to its unique facts," and that juvenile had no constitutional right to counsel's presence at post-fact-finding predisposition diagnostic mental study); People v Hana, 443 Mich 202, 504 NW2d 166, 174-75 (1993), cert denied as Hana v Michigan, $114 \mathrm{~S} \mathrm{Ct} 1074$ (1994) (distinguishing Estelle as applying only to cases involving use of admissions and statements made during psychiatric interviews after a determination of guilt).

Iis See, for example, R.H., 777 P2d at 208-10.

119 Feld, 69 Minn L Rev at 269 (cited in note 34).
} 
and due process required under Kent, and because involuntary statements at such a hearing are sufficiently incriminating to fall within the scope of the privilege.

It should be noted that at least one court has refused to extend the privilege on the ground that there is no constitutional right to be treated as a juvenile. ${ }^{120}$ This justification for denying the privilege simply begs the question. It is well documented that juvenile status is statutorily conferred, not constitutionally mandated; but the source of the states' authority to maintain juvenile jurisdiction has little bearing on the application of the privilege against self-incrimination to waiver hearings. Statements posing a threat of significant self-incrimination may fall within the scope of the Fifth Amendment, regardless of the origin of the proceeding. If the analysis reveals that the privilege applies to the waiver hearing and that the relevant statements are within the scope of the privilege, then juveniles are protected.

\section{A. The Privilege is a Component of Fundamental Due Process under Kent}

In order to extend the privilege to statements at the waiver hearing, the privilege must be considered a "basic requirement[ ] of due process and fairness" under Kent. ${ }^{121}$ In Gault, the Court implemented the principles of Kent by comparing the value of the proposed procedural safeguard with the impact its application would have on the juvenile court system. Significantly, the Gault Court found that due process and basic fairness mandated the extension of the privilege to juvenile delinquency hearings despite the noncriminal nature of those proceedings. ${ }^{122}$ The Gault Court considered the difficulties the privilege could create for the juvenile justice system, but found that the purpose of the privilege and the potential consequences of the delinquency proceeding overrode those concerns. ${ }^{123}$ The Court emphasized that the privilege helps assure the reliability of admissions and confessions and prevents states from eliminating a juvenile's freedom to decide whether to assist the state. ${ }^{124}$

120 See text accompanying notes 92-93.

121383 US at 553.

122 See text accompanying notes 51-56.

123387 US at 55 ("We conclude that the constitutional privilege against self-incrimination is applicable in the case of juveniles as it is with respect to adults. We appreciate that special problems may arise ... and that there may well be some differences in technique-but not in principle-depending upon the age of the child and the presence and competence of parents.").

124 See text accompanying notes 81, 85. See also Feld, 69 Minn L Rev at 154 (cited in 
Although many courts have debated whether the privilege is "fundamental" to due process at the waiver hearing, few have applied the type of analysis suggested by Gault and its progeny-balancing the individual's interest in the protection of the privilege against the state's interests in fair, flexible, and discretionary juvenile waiver proceedings. Such an analysis leads to the conclusion that the privilege is a component of fundamental due process at the waiver hearing. Juveniles face significant penalties at waiver hearings, including long periods of incarceration if waiver is successful. The privilege also helps protect them from loss of liberty as a result of coerced statements or inaccurate fact-finding. ${ }^{125}$

Contrary to claims made by courts denying the privilege, ${ }^{126}$ the extension of this crucial protection imposes limited costs on the flexibility and discretion of the waiver hearing. While other safeguards might unnecessarily reduce the juvenile court's discretion, extending the privilege would merely require courts to exercise their discretion within the limits of the privilege. All procedural protections impose some restrictions on the juvenile court's-and thus the state's-discretion. The true question is whether the protection of the individual juvenile defendant outweighs those costs. In the case of the privilege against self-incrimination, those costs must be borne by society if society is to maintain some degree of control over state authority in juvenile cases. ${ }^{127}$

Applying the privilege to the juvenile waiver hearing will not hinder courts' efforts to assess a juvenile's amenability to treatment. First, the fact that a juvenile may claim the privilege does not mean that she necessarily will. Children often cooperate fully with the courts, giving confessions and agreeing to psychiatric examinations in an attempt to receive leniency or to substantiate their amenability. ${ }^{128}$ Second, if the juvenile does exercise her privilege, the court can still draw conclusions from evidence other than the defendant's own compelled testimony. Information needed to determine amenability to treatment can be derived from the statements of other witnesses, the juvenile's criminal history, and

note 34) (The Gault Court found that "the procedural safeguards associated with the adversarial process were essential in juvenile proceedings, both to determine the truth and to preserve individual freedom by limiting the power of the state.").

${ }_{125}$ See text accompanying notes 25-46.

${ }^{125}$ See text accompanying notes 92-103.

127 See Berger, Taking the Fifth at 41 (cited in note 83).

${ }^{123}$ See, for example, Gault, 387 US at 44-46. 
other standard criteria. In short, extending the privilege merely precludes the use of involuntary, self-incriminating statements; it does not threaten the discretion of juvenile court judges or the informality of the proceedings.

B. Statements at the Waiver Hearing Fall within the Scope of the Privilege

Even if the privilege is an element of basic fairness and fundamental due process at the waiver hearing, it does not necessarily protect juveniles against coerced statements that might increase the likelihood of waiver. The privilege against self-incrimination is limited to compelled statements of a testimonial nature that may tend to incriminate the defendant. Whether coerced statements used at waiver hearings are covered by the privilege depends upon the meaning of the term "incriminate." Thus, a second tier of analysis is necessary to determine whether such statements fall within the scope of the privilege.

The term "incriminate" has been broadly construed. The Court has held that a defendant's testimony falls within the scope of the privilege if it provides "a link in the chain of evidence needed to prosecute the claimant for a [ ] crime."129 In juvenile court, evidence used to support waiver provides this link to prosecution: a child can be prosecuted and tried in an adult criminal proceeding as long as the juvenile court waives jurisdiction over that child. Thus, any evidence that triggers the waiver of a juvenile to adult court is a link in the chain of evidence making criminal prosecution of that juvenile possible. This view is consistent with Kent's characterization of the waiver hearing as a critical proceeding. ${ }^{130}$

Although evidence presented must "incriminate" the defendant, it need not be offered during a "criminal proceeding." The reach of the privilege was duly noted in Lefkowitz $v$ Turley:

The [Fifth] Amendment not only protects the individual against being involuntarily called as a witness against himself in a criminal prosecution but also privileges him not to answer official questions put to him in any other proceeding, civil or criminal, formal or informal, where the answers might incriminate him in future criminal proceedings. ${ }^{131}$

120 Hoffman, 341 US at 486 .

383 US at 556.

${ }^{131} 414$ US 70, 77 (1973). See also McCarthy v Arndstein, 266 US 34, 40 (1924) (The 
Whether the privilege applies does not hinge upon the nature of the proceeding in which the testimony is given. In United States $v$ Ward, the Court noted that if a proceeding has consequences that are sufficiently punitive, the privilege must be applied. ${ }^{132}$ The Gault Court similarly held that "the availability of the privilege does not turn upon the type of proceeding in which its protection is invoked, but upon the nature of the statement or admission and the exposure which it invites." 133 Despite the reasoning of some courts declining to extend the privilege, the privilege against self-incrimination is not limited to proceedings which determine guilt or innocence. Furthermore, the fact that the consequences of waiver are labelled as civil rather than criminal is not dispositive for purposes of the Fifth Amendment. If the defendant proves that a particular consequence is so punitive in purpose or effect that it cannot be considered civil, the proceeding is viewed as criminal and the privilege against self-incrimination applies. ${ }^{134}$

Although the Supreme Court refused to extend the privilege to involuntary commitment proceedings in Allen $v$ Illinois, ${ }^{135}$ the nature of the juvenile waiver hearing distinguishes that case. In Allen, the petitioner claimed that he should receive the protection of the privilege against self-incrimination at an involuntary commitment proceeding. The Court rejected his argument on the grounds that civil commitment has no criminal consequences and is not punitive in purpose or effect. ${ }^{136}$

The Allen ruling, however, does not alter the analysis in this Comment: the juvenile waiver hearing-which has as its direct consequence a criminal prosecution-can be seen as punitive in both purpose and effect. ${ }^{137}$ First, the juvenile waiver hearing is not a neutral proceeding pursuing the best interests of both child and society. The simple fact that the child is opposing a transfer that the state is seeking shows that the waiver hearing is not "neutral," hardly "benevolent," and not at all "designed for the protection of children." ${ }^{\prime 38}$

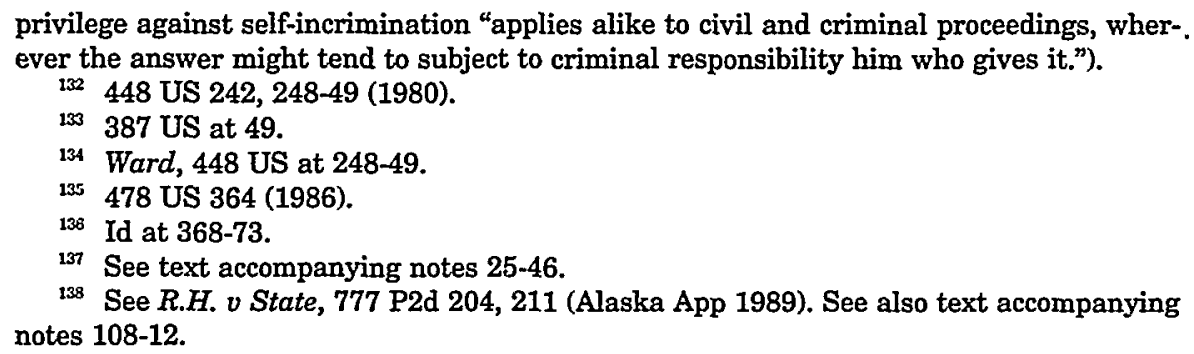


Second, waiver is fundamentally inconsistent with the parens patriae foundation of the juvenile justice system. Juvenile courts are supposed to act in the best interests of society and the child. Certainly, no court would claim that waiver to the adult criminal justice system is in the best interest of a fourteen-year-old child. The severe consequences of waiver and the punitive goals of the adult criminal justice system preclude any claim that the court has weighed the child's interests against that of the state. A court that waives a juvenile to adult court chooses to protect society at any cost to the young defendant before it. At the waiver hearing, the juvenile court abdicates its parens patriae duty to oversee a proceeding where the juvenile's interests are considered.

It seems difficult to deny that waiver is intended to penalize juveniles charged with particularly heinous crimes or thought to have particularly difficult psychological problems. As one commentator notes: "When all options have been tried and when criminality persists, the court administers the ultimate punishment and remands the youth to adult court." ${ }^{\text {"139 }}$ Even if waiver is not the "ultimate punishment" decried by the courts relying on Estelle $v$ Smith to extend the privilege ${ }^{140}$ waiving a juvenile to the adult criminal justice system still manifests the state's intent to punish the child as an adult. It reflects a decision to try the child in the punitive adult criminal justice system rather than the primarily "rehabilitative" juvenile system. This punitive intent, despite attempts to label waiver as merely a forum choice, mandates the application of the privilege to protect juveniles from compelled self-incrimination.

Waiver can also have a significant punitive effect. Juveniles waived to adult criminal court face a greater period of pretrial detention, a greater likelihood of conviction, and more severe sentences than their counterparts in juvenile court. Adult criminal prisons also offer fewer and less extensive treatment opportunities that do juvenile facilities. ${ }^{141}$

The significant punitive component of a juvenile waiver hearing trumps the state's characterization of the proceedings as civil. Mandatory psychiatric examinations and compelled statements or confessions provide a link in the chain of criminal prosecution. Through waiver proceedings, juveniles are subjected to tangible,

139 Barnes and Franz, 6 Just $Q$ at 134 (cited in note 39).

140 See text accompanying notes 113-19.

141 See text accompanying notes 27-38. 
identifiable penalties. When prosecutors attempt to use a juvenile's compelled or coerced statements against her for the purpose of waiver, those statements should fall under the protective scope of the privilege against self-incrimination.

\section{CONCLUSION}

The privilege against self-incrimination is an important procedural safeguard that should be extended to the juvenile waiver hearing to prevent courts from using a child's own statements to support the waiver of that child to adult court. The increased use of waiver in the criminal justice system demonstrates the pressing need for this result. The organizing principle suggested by this Comment furnishes the appropriate route by which this result can be reached. First, the privilege should apply in the waiver hearing because it is a component of basic fairness and due process; it promotes accurate fact-finding and prevents government coercion of children. Second, compelled statements that are used at waiver hearings fall within the scope of the privilege because they tend to incriminate the juvenile. Juveniles compelled to make a statement or required to undergo a psychiatric examination are forced to participate in a proceeding that potentially leads to their own criminal prosecution.

The juvenile justice system is valuable because it allows courts to use discretion in dealing with juvenile offenders. Exercise of that discretion requires freedom from the rigid procedures of adult criminal court. However, that discretion must never be exercised at the expense of a child's right to basic due process and fairness. When a proceeding poses such serious consequences for children as those presented by the juvenile waiver hearing, the state's first priority must be to protect those children through the application of our Constitution's most basic guarantees. 
" 